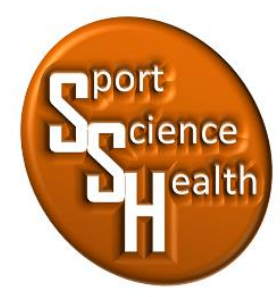

ISSN 2715-3886

\title{
Survei Tingkat Kebugaran Jasmani Tim Bola Basket
}

\author{
Dwi Yuda Setia ${ }^{1 *}$, M.E Winarno ${ }^{2}$ \\ 1,2Jurusan Pendidikan Jasmani, Kesehatan dan Rekreasi, Fakultas IImu Keolahragaan, \\ Universitas Negeri Malang, Jalan Semarang No 5, Malang, Jawa Timur, 65145, Indonesia \\ *Penulis koresponden: dwiyuda2@gmail.com, 087702153565
}

Artikel diterima: 26 November 2020; direvisi: 10 Maret 2021; disetujui: 20 Maret 2021

\begin{abstract}
Researchers who found that most of the basketball athletes of the State University of Malang had poor bodycondition. The purpose of this study was to determine and assess the level of physical fitness of the basketball team, State University of Malang. The research method used is survey method. The results showed that the highest category of physical fitness in men's basketball team athletes mostlyin the medium category with a percentage gain of $56.7 \%$, for the less category got a percentage of $36.7 \%$, and for the good category it was $3.3 \%$ and for the poor category the percentage was $3.3 \%$. The conclusion of the research results is that physical fitness level of the men's basketball team at the State University of Malang for the speed aspect is in the medium category while the women's team is in good category, arm muscle strength is in low category while the women's team is poor, the abdominal muscle strength for the men's team and women's team in good category, the muscle explosive power of the men's team and women's team in moderate category, the heart endurance of the men's team in moderate category, while the women's team was in poor category.
\end{abstract}

Keyword: physical fitness, basketball

\begin{abstract}
Abstrak: Kebugaran jasmani dalam sebuah permainan bola basket sangat dibutuhkan karena olahraga inibersifat aktif, dinamis dan memiliki tem po tinggi. Peneliti menemukan sebagian besar atletbola basket Universitas Negeri Malang memiliki kondisi tubuh yang kurang prima. Hal ini disebabkan oleh intensitas latihan yang kurang sehingga kondisi fisik atlet kurang prima. Adapun penelitian ini bertujuan untuk mengetahui dan mengkaji tingkat kebugaran jasmani tim bola basket Universitas Negeri Malang. Metode penelitian yang digunakan adalah metode survei.Hasil penelitian menunjukkan bahwa kebugaran jasmani atlet tim bola basket Universitas Negeri Malang secara keseluruhan yaitu pada kategori sedang memperoleh persentase sebesar $56,7 \%$, kategori kurang memperoleh persentase sebesar 36,7\%, kategori baik memperoleh persentase sebesar 3,3\% dan kategori kurang sekali memperoleh persentase sebesar 3,3\%. Simpulan hasil penelitian yaitu tingkat kebugaran jasmani tim bola basket putra Universitas Negeri malang untuk aspek kecepatan termasuk dalam kategori sedang sedangkan tim putri termasuk kategori baik, kekuatan otot lengan termasuk kategori kurang sekali sedangkan tim putri temasukkategori kurang, kekuatan otot perut tim putra dan tim putri termasuk kategori baik, daya ledak otot tim putra dan tim putri termasuk dalam kategori sedang, daya tahan jantung tim putra termasuk kategori sedang sedangkan tim putri termasuk kategori kurang.
\end{abstract}

Kata kunci: kebugaran jasmani, bola basket 


\section{PENDAHULUAN}

Olahraga merupakan aktivitas atau kegiatan fisik yang dilakukan oleh sebagian besar orang dengan tujuan menjaga serta meningkatkan kebugaran jasmani sehingga dapat melakukan kegiatan rutin secara maksimal dan tidak merasakan lelah yang berlebihan (Dugan, Gabriel, Lange-Maia, \& Karvonen-Gutierrez, 2018; Pfeifer \& Rütten, 2017; Piercy et al., 2018). Hasil dari latihan fisik setiap orang juga akan berbeda tergantung dari waktu dan kerutinannya dalam melatih fisik tubuhnya (Feofanov, Nekrasova, Boldov, \& Gusev, 2019; Khatuyev, Gilyasova, \& Konopleva, 2019; Perić, 2018). Menurut Budi \& Sugiharto (2015), pembinaan kondisi fisik merupakan pembinaan awal sebagai dasar pokok dalam mengikuti pelatihan olahraga untuk mencapai prestasi.

Fauziono (2013) menjelaskan bahwa kondisi fisik merupakan kemampuan yang dimiliki seseorang untuk mencapai target dari suatu olahraga tertentu secara optimal. Kondisi fisik seseorang terdiri dari beberapa komponen yang terdiri dari daya tahan otot, kekuatan, kelincahan, kecepatan, power, fleksibilitas, daya tahan jantung dan paru Fenanlampir, A., \& Faruq (2014). Menurut Zhu, dkk (2017) kebugaran fisik umumnya terdiri dari daya tahan kardiovaskuler, daya tahan otot, fleksibilitas dan komposisi tubuh yang merupakan bagian penting dari keseluruhan kesehatan fisik dan mental.

Semakin rutin latihan fisik yang dilakukan maka semakin tinggi pula produktivitas dan kebugaran jasmani seseorang (Golokova, Olenova, \& Nikolaev, 2019; Karpljuk, Šimenko, \& Karpljuk, 2015; Mokrova, Osipov, \& Nagovitsyn, 2019). Beberapa faktor yang dapat mempengaruhi tingkat kebugaran jasmani seseorang antara lain umur, jenis kelamin dan latihan (Abdillah, 2014). Untuk memperoleh kebugaran jasmani yang baik tidak hanya dari aktivitas fisik saja melainkan pola makan dan istirahat yang cukup (Prasetyo \& Winarno, 2019; Prayoga, Heynoek, \& Yudasamara, 2020). Hal ini dijelaskan oleh Sunardi (2013) bahwa untuk mendapatkan tubuh yang sehat dibutuhkan kombinasi tepat antara pola makan yang baik dan benar, latihan fisik yang tepat dan teratur dan istirahat yang cukup serta berkualitas.

Kebugaran jasmani sangat penting bagi mahasiswa terutama yang tergabung dalam tim bola basket Universitas Negeri Malang. Mahasiswa dengan kondisi tubuh yang bugar atau tidak mudah lelah dapat secara optimal melakukan aktivitas kuliah, latihan, dan bertanding. Atlet bola basket Universitas Negeri Malang memiliki kondisi tubuh yang kurang prima. Hal ini dapat dilihat dari hasil pertandingan Liga Mahasiswa Regional Jawa Timur yaitu Universitas Negeri Malang tidak dapat lolos ke Liga Mahasiswa Nasional.Hal ini disebabkan oleh faktor tertentu, menurut pelatih bola basket Universitas Negeri Malang faktor yang menyebabkan hal tersebut adalah intensitas latihan yang sangat kurang sehingga menyebabkan kondisi fisik atlet kurang prima, hal ini dikarenakan event Liga Mahasiswa Regional Jawa Timur diselenggarakan pada tanggal 24-31 Juli 2019 yang bertepatan dengan libur semester genap di Universitas Negeri Malang sehingga para atlet banyak yang pulang kampung dan latihan rutin dimulai dari 2 minggu sebelum event dimulai, sehingga dengan waktu 2 minggu pelatih sangat kesusahan untuk menyiapkan kondisi tim. Untuk masalah teknik dasar bola basket rata-rata atlet sudah sangat menguasai, sehingga hal yang paling diutamakan sekarang adalah kebugaran jasmani atlet.

Kebugaran jasmani dalam permainan basket sangat dibutuhkan karena olahraga ini bersifat aktif, dinamis dan memiliki tempo yang tinggi (French \& Thomas, 2016; Puente et al., 2017; Stöckel \& Vater, 2014). Dengan demikian perlu didukung dengan stamina dan mental yang baik serta kelincahan, ketangkasan, keterampilan gerak tipu mata, tangan dan kaki yang dikembangkan pada derajat seni kemahiran gerak. Dalam permainan bola basket bukan hanya permainan tim akan tetapi juga permainan individu sehingga setiap pemain dituntut untuk menjadi pemain bagus dalam timnya yang tidak mementingkan diri sendiri (Fame, 2017; Gong \& Ning, 2016). Kegiatan latihan tim bola basket Universitas Negeri Malang selama ini belum pernah dilakukan pengkajian tentang kondisi tingkat kebugaran jasmani. Oleh sebab itu penelitian ini bertujuan untuk mengetahui dan mengkaji tingkat kebugaran jasmani tim bola basket Universitas Negeri Malang. Dengan adanya penelitian ini, diharapkan dapat memberikan motivasi lebih kepada para atlet dan dapat membantu meningkatkan intensitas latihan.

\section{METODE}

Ditinjau dari masalah yang diteliti, maka penelitian ini menggunakan rancangan survei. Ditinjau dari tujuan penelitian, maka penelitian ini termasuk penelitian deskriptif. Menurut Winarno (2013) penelitian deskriptif 
bertujuan untuk mendeskripsikan suatu aktivitas/kegiatan atau peristiwa yang terjadi pada saat ini secara akurat dan sistematis dimana peneliti tidak perlu memberikan suatu perlakukan tetapi hanya mengumpulkan dan menganalisis data sesuai fakta yang terjadi di lapangan. Variabel yang diteliti berupa tingkat kebugaran jasmani terdiri dari kecepatan, kekuatan dan ketahanan otot lengan, kekuatan dan ketahanan otot perut, daya ledak otot tungkai, dan daya tahan tubuh.

Subjek dari penelitian ini adalah atlet dari tim bola basket putra dan putri dari Universitas Negeri Malang dimana fokus penelitiannya pada tingkat kebugaran jasmani dengan jumlah sebanyak 15 anggota dari tim bola basket putra dan 15 anggota dari tim bola basket putri.

Instrumen yang digunakan dalam penelitian ini adalah Tes Kebugaran Jasmani Indonesia (TKJI) yang terdiri dari tes lari 60 meter, tes angkat tubuh 60 detik, tes baring duduk 60 detik, tes loncat tegak, dan tes lari 1200 meter. Nilai korelasi tes kebugaran jasmani usia 16-19 tahun adalah 0,907 dan nilai reliabilitas 0,976.

Sesuai dengan tujuan dalam penelitian ini yaitu mengetahui tingkat kebugaran jasmani pada tim bola basket Universitas Negeri Malang dan dengan pertimbangan jenis data yang dikumpulkan berupa data ratio maka teknik analisis data yang digunakan adalah teknik statistik deskriptif berupa angka/hasil tertinggi, angka/hasil terendah, mean dan standar deviasi, variansi dan koefisien keragaman dari hasil tes kebugaran jasmani yang diperoleh dari pelaksanaan tes TKJI. Analisis data dalam penelitian ini menggunakan statistik deskriptif dengan menggunakan rumus:

$$
P=\frac{f}{n} \times 100 \%
$$

\section{Keterangan:}

$\begin{array}{ll}\mathrm{P} & : \text { Persentase } \\ \mathrm{f} & : \text { Jumlah atlet setiap kategori } \\ \mathrm{N} & : \text { Jumlah keseluruhan sampel }\end{array}$

\section{HASIL}

Secara keseluruhan hasil Survei Kebugaran Jasmani Atlet Bola Basket Putra UM diuraikan sebagai berikut.

Tabel 1. Data Kebugaran Jasmani Atlet Bola Basket Putra UM

\begin{tabular}{lllllll}
\hline No & Variabel & $\begin{array}{l}\text { Skor } \\
\text { minimal }\end{array}$ & $\begin{array}{l}\text { Skor } \\
\text { maksimal }\end{array}$ & Jumlah & Rerata & $\begin{array}{l}\text { Standar } \\
\text { Deviasi }\end{array}$ \\
\hline 1 & Kecepatan & 9,79 & 8,13 & 134,28 & 8,95 & 0,57 \\
2 & Kekuatan otot lengan & 2 & 10 & 71 & 4,73 & 2,25 \\
3 & Kekuatan otot perut & 26 & 38 & 481 & 32,07 & 4,18 \\
4 & Daya Ledak & 30 & 72 & 787 & 52,47 & 12,38 \\
5 & Daya Tahan Jantung & 6,2 & 4,22 & 79,36 & 5,29 & 0,74 \\
\hline
\end{tabular}

Selanjutnya dijelaskan distribusi data hasil penelitian masing-masing tes sebagai berikut.

\section{Kecepatan (Sprint 60 meter)}

Tabel 2. Hasil tes sprint 60 meter

\begin{tabular}{llll}
\hline Nilai & Jumlah & $\%$ & Keterangan \\
\hline 5 & 0 & 0 & Baik sekali \\
4 & 2 & 13,3 & Baik \\
3 & 10 & 66,7 & Sedang \\
2 & 3 & 20 & Kurang \\
1 & 0 & 0 & Kurang sekali \\
\hline Total & 15 & $100 \%$ & \\
\hline
\end{tabular}




\section{Kekuatan Otot Lengan (Angkat tubuh)}

Tabel 3. Hasil tes angkat tubuh

\begin{tabular}{llll}
\hline Nilai & Jumlah & $\%$ & Keterangan \\
\hline 5 & 0 & 0 & Baik sekali \\
4 & 0 & 0 & Baik \\
3 & 2 & 13,3 & Sedang \\
2 & 3 & 20 & Kurang \\
1 & 10 & 66,7 & Kurang sekali \\
\hline Total & 15 & $100 \%$ & \\
\hline
\end{tabular}

\section{Kekuatan Otot Perut (Baring duduk)}

Tabel 4. Hasil tes baring duduk

\begin{tabular}{llll}
\hline Nilai & Jumlah & $\%$ & Keterangan \\
\hline 5 & 0 & 0 & Baik sekali \\
4 & 11 & 73,3 & Baik \\
3 & 4 & 26,7 & Sedang \\
2 & 0 & 0 & Kurang \\
1 & 0 & 0 & Kurang sekali \\
\hline Total & 15 & $100 \%$ & \\
\hline
\end{tabular}

Daya Ledak (Loncat Tegak)

Tabel 5. Hasil tes loncat tegak

\begin{tabular}{llll}
\hline Nilai & Jumlah & $\%$ & Keterangan \\
\hline 5 & 0 & 0 & Baik sekali \\
4 & 5 & 33,3 & Baik \\
3 & 6 & 40 & Sedang \\
2 & 4 & 26,7 & Kurang \\
1 & 0 & 0 & Kurang sekali \\
\hline Total & 15 & $100 \%$ & \\
\hline
\end{tabular}

\section{Daya Tahan Jantung (Lari 1200 meter)}

Tabel 6. Hasil tes loncat tegak

\begin{tabular}{llll}
\hline Nilai & Jumlah & $\%$ & Keterangan \\
\hline 5 & 0 & 0 & Baik sekali \\
4 & 0 & 0 & Baik \\
3 & 7 & 46,7 & Sedang \\
2 & 7 & 46,7 & Kurang \\
1 & 1 & 6,6 & Kurang sekali \\
\hline Total & 15 & $100 \%$ & \\
\hline
\end{tabular}

Setelah hasil data dideskripsikan satu persatu, langkah selanjutnya adalah menggabungkan total dari keseluruhan nilai. Dari kelima butir tes, diperoleh hasil sebagai berikut:

Tabel 7. Hasil tes loncat tegak

\begin{tabular}{llll}
\hline Nilai & Jumlah & $\%$ & Keterangan \\
\hline 5 & 0 & 0 & Baik sekali \\
4 & 1 & 6,6 & Baik \\
3 & 7 & 46,7 & Sedang \\
2 & 7 & 46,7 & Kurang \\
1 & 0 & 0 & Kurang sekali \\
\hline Total & 15 & $100 \%$ & \\
\hline
\end{tabular}


Secara keseluruhan hasil Survei Kebugaran Jasmani Atlet Bola Basket Putra UM diuraikan sebagai berikut.

Tabel 8. Data Kebugaran Jasmani Atlet Bola Basket Putra UM

\begin{tabular}{lllllll}
\hline Nilai & Jumlah & $\%$ & Keterangan & Nilai & Jumlah & $\%$ \\
\hline 5 & 0 & 0 & Baiksekali & 5 & 0 & 0 \\
4 & 1 & 6,6 & Baik & 4 & 1 & 6,6 \\
3 & 7 & 46,7 & Sedang & 3 & 7 & 46,7 \\
2 & 7 & 46,7 & Kurang & 2 & 7 & 46,7 \\
1 & 0 & 0 & Kurangsekali & 1 & 0 & 0 \\
\hline
\end{tabular}

\section{Kecepatan (Sprint 60 meter)}

Tabel 9. Hasil Tes Sprint 60 Meter

\begin{tabular}{llll}
\hline Nilai & Jumlah & $\%$ & Keterangan \\
\hline 5 & 0 & 0 & Baik sekali \\
4 & 8 & 53,3 & Baik \\
3 & 6 & 40 & Sedang \\
2 & 1 & 6,7 & Kurang \\
1 & 0 & 0 & Kurang sekali \\
\hline Total & 15 & $100 \%$ & \\
\hline
\end{tabular}

\section{Kekuatan Otot Lengan (Siku Tekuk)}

Tabel 10. Hasil Tes Siku Tekuk

\begin{tabular}{llll}
\hline Nilai & Jumlah & $\%$ & Keterangan \\
\hline 5 & 0 & 0 & Baik sekali \\
4 & 0 & 0 & Baik \\
3 & 0 & 0 & Sedang \\
2 & 10 & 66,7 & Kurang \\
1 & 5 & 33,3 & Kurang sekali \\
\hline Total & 15 & $100 \%$ & \\
\hline
\end{tabular}

\section{Kekuatan Otot Perut (Baring duduk)}

Tabel 11. Hasil Tes Baring Duduk

\begin{tabular}{llll}
\hline Nilai & Jumlah & $\%$ & Keterangan \\
\hline 5 & 0 & 0 & Baik sekali \\
4 & 9 & 60 & Baik \\
3 & 6 & 40 & Sedang \\
2 & 0 & 0 & Kurang \\
1 & 0 & 0 & Kurang sekali \\
\hline Total & 15 & $100 \%$ & \\
\hline
\end{tabular}

\section{Daya Ledak Otot Tungkai (Loncat Tegak)}

Tabel 12. Hasil Tes Loncat Tegak

\begin{tabular}{llll}
\hline Nilai & Jumlah & $\%$ & Keterangan \\
\hline 5 & 0 & 0 & Baik sekali \\
4 & 3 & 20 & Baik \\
3 & 7 & 46,7 & Sedang \\
2 & 5 & 33,3 & Kurang \\
1 & 0 & 0 & Kurang sekali \\
\hline Total & 15 & $100 \%$ & \\
\hline
\end{tabular}




\section{Daya Tahan Jantung (Lari 1000 meter)}

Tabel 13 Hasil Tes Lari 1000 Meter

\begin{tabular}{llll}
\hline Nilai & Jumlah & $\%$ & Keterangan \\
\hline 5 & 0 & 0 & Baik sekali \\
4 & 0 & 0 & Baik \\
3 & 0 & 0 & Sedang \\
2 & 11 & 73,3 & Kurang \\
1 & 4 & 26,7 & Kurang sekali \\
\hline Total & 15 & $100 \%$ & \\
\hline
\end{tabular}

Secara keseluruhan hasil Survei Kebugaran Jasmani Atlet Bola Basket Putri UM diuraikan sebagai berikut.

Tabel 14 Hasil Kebugaran Jasmani Atlet Bola Basket Putri UM

\begin{tabular}{llll}
\hline Nilai & Jumlah & $\%$ & Keterangan \\
\hline 5 & 0 & 0 & Baik sekali \\
4 & 0 & 0 & Baik \\
3 & 10 & 66,7 & Sedang \\
2 & 4 & 26,7 & Kurang \\
1 & 1 & 6,6 & Kurang sekali \\
\hline Total & 15 & $100 \%$ & \\
\hline
\end{tabular}

\section{PEMBAHASAN}

Kebugaran jasmani merupakan salah satu faktor yang penting bagi seorang mahasiswa, terutama yang tergabung dalam tim bola basket Universitas Negeri Malang. Mahasiswa dengan kondisi tubuh yang bugar tidak akan mudah lelah melakukan aktivitas kuliah, latihan, dan bertanding.

\section{Kecepatan Tim Bola Basket Putra Universitas Negeri Malang}

Hasil penelitian menunjukkan bahwa kecepatan tim bola basket putra Universitas Negeri Malang termasuk dalam kategori sedang. Hal tersebut selaras dengan temuan Priambodo (2013) yang menunjukkan bahwa kecepatan atlet putra bola basket PPLP di Jawa Tengah termasuk dalam kategori sedang. Penelitian Prabowo (2013) juga menemukan hal yang sama yakni kecepatan siswa putra yang mengikuti ekstrakurikuler bola basket di SMA 1 Bantul termasuk dalam kategori sedang. Hal ini kemungkinan dipengaruhi oleh durasi dan model latihan yang digunakan pada saat latihan. Siswa yang mengikuti ekstrakurikuler bola basket masih memiliki kegiatan lain di sekolah sehingga sering berbenturan dengan waktu ekstrakulikuler bola basket. Akibatnya, durasi waktu latihan akan berkurang. Namun, berbeda pada penelitian herman, dkk (2018) yang menunjukkan kecepatan atlet bola basket putra tim PON XIX Sul-Sel termasuk dalam kategori baik. Sedangkan pada penelitian Fadil (2018) menunjukkan kecepatan siswa SMA 2 Pangkep yang mengikuti ekstrakurikuler bola basket termasuk dalam kategori baik sekali.

\section{Kekuatan dan Ketahanan Otot Lengan Tim Bola Basket Putra Universitas Negeri Malang}

Hasil penelitian menunjukkan bahwa kekuatan otot lengan tim bola basket putra Universitas Negeri malang termasuk dalam kategori kurang sekali. Hal tersebut berbeda juga dengan penelitian Prabowo (2013) bahwa kekuatan otot lengan siswa putra yang mengikuti ekstrakurikuler bola basket di SMA 1 Bantul termasuk dalam kategori sedang. Pada penelitian Fadil (2018) menunjukkan hasil yang berbeda juga yakni kekuatan otot lengan siswa SMA 2 Pangkep yang mengikuti ekstrakurikuler bola basket termasuk dalam kategori baik. Sedangkan pada penelitian herman, dkk (2018) menunjukkan kekuatan otot lengan atlet bola basket putra tim PON XIX Sulsel termasuk dalam kategori sedang.

\section{Kekuatan Otot Perut Tim Bola Basket Putra Universitas Negeri Malang}

Hasil penelitian menunjukkan bahwa kekuatan otot lengan tim bola basket putra Universitas Negeri malang termasuk dalam kategori baik. Hal tersebut serupa dengan penelitian Prabowo (2013) yang menunjukkan bahwa kekuatan otot perut siswa putra yang mengikuti ekstrakurikuler bola basket di SMA 1 Bantul termasuk dalam kategori baik. Hasil penelitian Fadil (2018) juga menunjukkan hal yang sama bahwa kekuatan otot perut 
siswa SMA 2 Pangkep termasuk dalam kategori baik. Namun, hal tersebut berbeda dari penelitian Priambodo (2013) yang satu tingkat lebih baik bahwa kekuatan otot perut atlet putra bola basket PPLP di Jawa Tengah termasuk dalam kategori baik sekali. Oleh karena kekuatan otot perut tim putra bola basket Universitas Negeri Malang termasuk dalam kategori baik maka harus dipertahankan guna menunjang atlet melakukan gerakan yang membutuhkan kekuatan otot perut pada saat bertanding.

\section{Daya Ledak Otot Tungkai Tim Bola Basket Putra Universitas Negeri Malang}

Hasil penelitian menunjukkan bahwa daya ledak otot tungkai tim bola basket putra Universitas Negeri malang termasuk dalam kategori sedang. Hal ini serupa dengan penelitian Prabowo (2013) yang menunjukkan bahwa daya ledak otot tungkai siswa putra yang mengikuti ekstrakurikuler bola basket di SMA 1 Bantul termasuk dalam kategori sedang. Pada penelitian Prihanto \& Wismanadi (2016) juga menunjukkan daya ledak otot tungkai atlet bola basket putra SMA Trimurti Surabaya termasuk dalam kategori sedang. Berbeda dengan penelitian Priambodo (2013) yang menunjukkan bahwa daya ledak otot tungkai putra bola basket PPLP di Jawa Tengah termasuk dalam kategori baik. Kemudian, pada penelitian Fadil (2018) juga menunjukkan hasil yang berbeda bahwa daya ledak otot tungkai siswa SMA 2 Pangkep termasuk dalam kategori baik. Hasil penelitian mengenai daya ledak tim bola basket putra UM yang termasuk dalam kategori sedang perlu dilatih lagi agar dapat melompat dengan baik pada saat bertanding.

\section{Daya Tahan Jantung Tim Bola Basket Putra Universitas Negeri Malang}

Hasil penelitian menunjukkan bahwa daya tahan jantung tim bola basket putra Universitas Negeri malang termasuk dalam kategori sedang. Hal ini serupa dengan penelitian Prabowo (2013) yang menunjukkan bahwa daya tahan jantung siswa putra yang mengikuti ekstrakurikuler bola basket di SMA 1 Bantul termasuk dalam kategori sedang. Namun, berbeda dengan penelitian Priambodo (2013) yang satu tingkat lebih rendah yakni daya tahan jantung atlet putra bola basket PPLP di Jawa Tengah termasuk dalam kategori kurang. Sedangkan pada penelitian Fadil (2018) menunjukkan daya tahan jantung siswa SMA 2 Pangkep termasuk dalam kategori baik.

\section{Kecepatan Tim Bola Basket Universitas Negeri Malang}

Hasil penelitian menunjukkan bahwa kecepatan tim bola basket putri Universitas Negeri Malang termasuk dalam kategori baik. Hal ini serupa dengan penelitian Prawira (2013) yang menunjukkan kecepatan atlet bola basket putri SMA 3 Payakumbuh termasuk dalam kategori baik. Penelitian Mylsidayu \& Kurniawan (2016) juga menunjukkan hal yang sama bahwa kecepatan atlet bola basket putri PPLPD Kabupaten Bogor termasuk dalam kategori baik. Berbeda dengan penelitian herman, dkk (2018) yang menunjukkan bahwa kekuatan atlet bola basket putri tim PON XIX Sulsel termasuk dalam kategori sedang.

\section{Kekuatan dan Ketahanan Otot Lengan Tim Bola Basket Putri Universitas Negeri Malang}

Hasil penelitian menunjukkan bahwa kekuatan otot lengan tim bola basket putri Universitas Negeri malang termasuk dalam kategori kurang. Hal tersebut berbeda dari penelitian Mylsidayu \& Kurniawan (2016) yang menunjukkan kekuatan dan daya tahan otot lengan atlet bola basket putri PPLPD Kabupaten Bogor termasuk dalam kategori baik. Pada penelitian Herman, dkk (2018) juga menunjukkan perbedaan bahwa kekuatan otot lengan atlet bola basket putri tim PON XIX Sulsel termasuk dalam kategori kurang sekali.

\section{Kekuatan dan Ketahanan Otot Perut Tim Bola Basket Putri Universitas Negeri Malang}

Hasil penelitian menunjukkan bahwa kekuatan otot lengan tim bola basket putri Universitas Negeri malang termasuk dalam kategori baik. Hal tersebut serupa dengan penelitian Mylsidayu \& Kurniawan (2016) yang menunjukkan kekuatan dan daya tahan otot perut atlet bola basket putri PPLPD Kabupaten Bogor termasuk dalam kategori baik. Berbeda dengan penelitian Herman, dkk (2018) yang menunjukkan bahwa kekuatan otot perut atlet bola basket putri tim PON XIX Sulsel termasuk dalam kategori kurang.

\section{Daya Ledak Otot Tungkai Tim Bola Basket Putri Universitas Negeri Malang}

Hasil penelitian menunjukkan bahwa daya ledak otot tungkai tim bola basket putri Universitas Negeri malang termasuk dalam kategori sedang. Hal tersebut serupa dengan penelitian Prawira (2013) yang menunjukkan daya ledak otot tungkai atlet bola basket putri SMA 3 Payakumbuh termasuk dalam kategori sedang. Namun, berbeda dengan penelitian Mylsidayu \& Kurniawan (2016) yang menunjukkan daya ledak otot tungkai atlet bola basket putri PPLPD Kabupaten Bogor termasuk dalam kategori baik. Pada penelitian Herman, dkk (2018) 
juga menunjukkan perbedaan bahwa daya ledak otot tungkai atlet bola basket putri tim PON XIX Sulsel termasuk dalam kategori baik sekali.

\section{Daya Tahan Jantung Tim Bola Basket Putri Universitas Negeri Malang}

Hasil penelitian menunjukkan bahwa daya tahan jantung tim bola basket putra Universitas Negeri malang termasuk dalam kategori kurang. Hal tersebut berbeda dengan penelitian Mylsidayu \& Kurniawan (2016) yang menunjukkan daya tahan jantung atlet bola basket putri PPLPD Kabupaten Bogor termasuk dalam kategori baik. Pada penelitian Nugraha \& Rismayanthi (2017) juga menunjukkan bahwa daya tahan jantung atlet bola basket putri Kabupaten Indramayu termasuk dalam kategori sedang. Berdasarkan hasil penelitian menunjukkan kebugaran jasmani tim bola basket putra dan putri UM termasuk dalam kategori sedang yang kemungkinan dipengaruhi oleh beberapa faktor, antara lain:

\section{Durasi latihan}

Mahasiswa yang mengikuti UKM bola basket memiliki kegiatan baik di dalam dan diluar jam kuliah dimana kegiatan tersebut sering berbenturan dengan waktu latihan. Akibatnya, durasi latihan akan berkurang. Padahal keberhasilan untuk mencapai tingkat kebugaran jasmani ditentukan oleh kualitas latihan yang meliputi tujuan latihan, pemilihan model latihan dan dosis latihan. Dosis latihan meliputi frekuensi, intensitas, waktu latihan dan recovery. Oleh sebab itu diperlukan suatu pembagian waktu yang lebih baik lagi dari pelatih untuk mengatasi permasalahan durasi latihan sehingga diharapkan dosis latihan dalam upaya meningkatkan atau menjaga kebugaran jasmani mahasiswa sebagai pemain dapat tercapai.

\section{Model latihan}

Frekuensi latihan atlet bola basket Universitas Negeri Malang hanya dilakukan 3 kali dalam seminggu. Model latihan yang dilakukan lebih menekankan pada latihan teknik, taktik, kerjasama tim dan strategi sementara untuk latihan kebugaran jasmani kurang diperhatikan. Sehingga dengan melihat hasil pengukuran tes kebugaran yang sebagian besar berada dalam kategori sedang perlu mendapatkan perhatian lebih. Oleh sebab itu dibutuhkan jalan keluar lain yang lebih baik lagi dalam menyusun suatu program latihan, sehingga komponen-komponen kebugaran jasmani yang dibutuhkan siswa sebagai pemain dapat mencapai kondisi yang maksimal.

\section{KESIMPULAN}

Berdasarkan hasil penelitian dapat disimpulkan bahwa kebugaran jasmani tim bola basket putra Universitas Negeri Malang untuk aspek kecepatan termasuk dalam kategori sedang sedangkan tim putri termasuk kategori baik, kekuatan otot lengan termasuk kategori kurang sekali sedangkan tim putri termasuk kategori kurang, kekuatan otot perut tim putra dan tim putri termasuk kategori baik, daya ledak otot tim putra dan tim putri termasuk dalam kategori sedang, daya tahan jantung tim putra termasuk kategori sedang sedangkan tim putri termasuk kategori kurang.

\section{DAFTAR PUSTAKA}

Abdillah, F. . (2014). Survei Tingkat Kapasitas Oksigen Maksimal Atlet PORPROV Kota Batu. Jurnal Sport Science, 4(3), 130-140.

Budi, M.F.S., \& S. (2015). Circuit Training dengan Rasio 1:1 dan Rasio 1:2 Terhadap Peningkatan VO2max. Journal of Sport Sciences and Fitness, 4(3), 53-58.

Dugan, S. A., Gabriel, K. P., Lange-Maia, B. S., \& Karvonen-Gutierrez, C. (2018). Physical Activity and Physical Function. Obstetrics and Gynecology Clinics of North America, 45(4), 723-736. https://doi.org/10.1016/j.ogc.2018.07.009

Fadil, A. . (2018). Analisis Tingkat Kesegaran Jasmani dan Keterampilan Dasar Bermain Bola Basket SMA Negeri 2 Pangkep. Universitas Negeri Makassar.

Fame, B. H. of. (2017). College basketball: Bill Self, Muffet McGraw and Rollie Massimino highlight the Naismith Memorial Basketball Hall of Fame finalists. NCAA News, 1. Retrieved from 
http://search.ebscohost.com/login.aspx?direct=true\&db=s3h\&AN=121347435\&site=ehost-live

Fauziono, A. (2013). Profil Kondisi Fisik Atlet Sepakbola SMA Negeri 3 Cimahi. Universitas Pendidikan Indonesia.

Fenanlampir, A., \& Faruq, M. . (2014). Tes dan Pengukuran dalam Olahraga. YOGYAKARTA: CV. Andi Offset.

Feofanov, V. N., Nekrasova, M. V., Boldov, A. S., \& Gusev, A. V. (2019). Gender features of agresive and hostile reactions of students with diferent physical fitnes levels. Teoriya I Praktika Fizicheskoy Kultury, 2019(5), 20-21.

French, K. E., \& Thomas, J. R. (2016). The Relation off Knowledge Development to Children's Basketball Performance. Journal of Sport Psychology, 9(1), 15-32. https://doi.org/10.1123/jsp.9.1.15

Herman dkk. (2018). Analisis Physical Fitnes Atlet Bolabasket Tim PON Ke XIX Sul-Sel. Journal of Physical Education, Sport and Recreation, Vol 2(1), 1-9.

Golokova, V. S., Olenova, A. A., \& Nikolaev, N. D. (2019). Enhancing physical fitnes of wrestlers with hearing impairment by means of hapsagay wrestling. Teoriya I Praktika Fizicheskoy Kultury.

Gong, C., \& Ning, C. (2016). Motion simulation in a virtual basketball shooting teaching system. International Journal of Online Engineering, 12(2), 55-57. https://doi.org/10.3991/ijoe.v12i02.5049

Karpljuk, D., Šimenko, J., \& Karpljuk, D. (2015). Specialni judo fitnes test. Sport: Revija Za Teoreticna in Prakticna Vprasanja Sporta, 63(1/2), 42-46.

Khatuyev, Z. A., Gilyasova, M. K., \& Konopleva, A. N. (2019). Computer stabilography in students' physical development and fitnes monitoring system. Teoriya I Praktika Fizicheskoy Kultury, 2019(7), 12.

Mokrova, T. I., Osipov, A. Y., \& Nagovitsyn, R. S. (2019). Modern types of fitnes practices in academic physical education (kango -jump fitnes). Teoriya I Praktika Fizicheskoy Kultury, 2019(7), 104.

Mylsidayu, A., \& Kurniawan, F. (2016). Survei Kesegaran Jasmani Atlet Bola Bakset PLPD Kabupaten Bogor. Jurnal Motion, 7(2), 191-202.

Nugraha, M. F. A. (2017). Profil Daya Tahan Aerobik Posisi Guard, Forward dan Center Atlet Bola Basket Kabupaten Indramayu. Universitas Negeri Yogyakarta.

Perić, D. (2018). Health Fitness - Truth or Marketing // Zdravstveni fitnes - istina ili marketing. Спортске Науке И Здравље - АПЕИРОН, 15(1). https://doi.org/10.7251/ssh1801052p

Pfeifer, K., \& Rütten, A. (2017). National Recommendations for Physical Activity and Physical Activity Promotion. Das Gesundheitswesen, 79(S 01), S2-S3. https://doi.org/10.1055/s-0042-123346

Piercy, K. L., Troiano, R. P., Ballard, R. M., Carlson, S. A., Fulton, J. E., Galuska, D. A., ... Olson, R. D. (2018). The physical activity guidelines for Americans. JAMA - Journal of the American Medical Association, 320(19), 2020-2028. https://doi.org/10.1001/jama.2018.14854

Prabowo, M. H. (2013). Tingkat Kebugaran Jasmani Siswa Putra yang Mengikuti Ekstrakulikuler Bola Basket di SMA 1 Bantul. Universitas Negeri Yogyakarta.

Prasetyo, M. A., \& Winarno, M. E. (2019). Hubungan Status Gizi Dan Aktivitas Fisik Dengan Tingkat Kebugaran Jasmani Pada Siswa SMP. Sport Science and Health, 1(3), 198-207. Retrieved from http://journal2.um.ac.id/index.php/jfik/index

Prawira, B. . (2013). Tinjauan Kondisi Fisik Atlet Bola Basket SMA Negeri 3 Payakumbuh. Jurnal Wisuda Periode 96.

Prayoga, G. A. N., Heynoek, F. P., \& Yudasamara, D. S. (2020). Pengembangan Model Pembelajaran Kebugaran Jasmani Dengan Modifikasi Permainan Pada Siswa Kelas VIII. Sport Science and Health, 2(10), 500-510. Retrieved from http://journal2.um.ac.id/index.php/jfik/index

Priambodo, A. (2013). Tingkat kesegaran jasmani atlet putra bolabasket pplp jawa tengah tahun 2013. Universitas Negeri Semarang.

Prihanto, K., \& Wismanadi, H. (2016). Analisis Kondisi Fisik Atlet Putra Klub Bola Basket SMA Trimurti 
Surabaya. Jurnal Kesehatan Olahraga, 6(2), 465-472.

Puente, C., Abián-Vicén, J., Salinero, J. J., Lara, B., Areces, F., \& Del Coso, J. (2017). Caffeine improves basketball performance in experienced basketball players. Nutrients, $9(9)$. https://doi.org/10.3390/nu9091033

Stöckel, T., \& Vater, C. (2014). Hand preference patterns in expert basketball players: Interrelations between basketball-specific and everyday life behavior. Human Movement Science, 38, 143-151. https://doi.org/10.1016/j.humov.2014.09.002

Sunardi, Y. (2013). Sehat tanpa Repot: Panduan untuk Memilih Makanan dan Minuman dengan Tepat untuk Hidup Sehat. Yogyakarta: Rapha Publishing.

Winarno, M. E. (2013). Metodologi Penelitian dalam Pendidikan Jasmani. Malang: Universitas Negeri Malang (UM Press).

Zhu, dkk. (2017). Prevalence of Physical Fitness in Chinese School-Age Children: Findings from the 2016 Physical Activity and Fitness in China-The Youth Study. Journal of Sport and Health Science, 1-9. 